Vol 1. No. 4, Oktober 2021 P-ISSN : 2774-8014, e-ISSN : 2774-7034

\title{
MENINGKATKAN KINERJA KEPALA MIN 6 SEMARANG MELALUI METODE SELF ASSESMENT
}

\author{
NUR SA'IDU \\ Pengawas Madrasah Kementerian Agama Kabupaten Semarang \\ e-mail: nuripurbosari68@gmail.com
}

\begin{abstract}
ABSTRAK
Penelitian ini bertujuan untuk mengetahui peningkatan Kinerja Kepala MIN 6 Semarang melalui Metode Self Assesment (Penilaian Diri Sendiri). Jenis penelitian ini adalah penelitian tindakan kepengawasan yang dilakukan secara kolaboratif partisipatif antara Kepala MIN 6 Semarang sebagai Subyek Penelitian dengan Pengawas Sekolah pada Madrasah sebagai Peneliti. Penelitian dilaksanakan dalam dua siklus, masing-masing siklus terdiri dari empat komponen yaitu perencanaan, tindakan, pengamatan, dan refleksi. Teknik pengumpulan data yang digunakan dalam penelitian ini adalah wawancara, observasi, dokumentasi, dan analisis data. Analisis data dilakukan dalam 3 tahap yaitu reduksi, penyajian data, dan penarikan kesimpulan. Hasil penelitian menunjukkan bahwa: (a) penggunaan metode Self Assesment (Penilaian Diri Sendiri) dapat meningkatkan kinerja Kepala MIN 6 Semarang . Peningkatan Kinerja Kepala MIN 6 Semarang dapat dilihat dari komponen Standar Kepribadian pada siklus 1 sebesar $80 \%$ meningkat menjadi sebesar 90,5\% pada siklus 2 atau naik sebesar 10,5\%. Standar Kompetensi Manajerial pada siklus 1 sebesar 76,4\% meningkat menjadi sebesar 89,3\% pada siklus 2 atau naik sebesar 12,3\%. Standar Kompetensi Kewirausahaan pada siklus 1 sebesar 76,25\% meningkat menjadi sebesar 91,25\% pada siklus 2 atau naik sebesar $15 \%$. Standar Kompetensi Supervisi pada siklus 1 sebesar $78 \%$ meningkat menjadi sebesar $86 \%$ pada siklus 2 atau naik sebesar 8\%. Standar Kompetensi Sosial pada siklus 1 sebesar 63,3\% meningkat menjadi sebesar 76\% pada siklus 2 atau naik sebesar 12,6\%. (b) Penggunaan Self Assesment (Penilaian Diri Sendiri) dapat meningkatkan Kinerja Kepala MIN 6 Semarang dengan rata-rata pada siklus 1 sebesar 74,8\% meningkat menjadi 86,6\% pada siklus 2 atau mengalami peningkatan sebesar $11,8 \%$.
\end{abstract}

Kata Kunci: Kinerja, Self Assesment (Penilaian Diri Sendiri), Kepala MIN 6 Semarang .

\section{PENDAHULUAN}

Manajemen peningkatan mutu Sekolah pada hakikatnya adalah suatu strategi untuk memperbaiki mutu pendidikan dengan jalan pemberian kewenangan dan tanggung jawab pengambilan keputusan kepala sekolah dengan melibatkan partisipasi individual, baik personal sekolah maupun anggota masyarakat. Dengan diterapkannya manajemen peningkatan mutu berbasis sekolah akan membawa perubahan terhadap pola manajemen pendidikan dari sistem sentralisasi ke desentralisasi. Desentralisasi merupakan pendekatan yang mempercayakan pengelolaan pendidikan kepada daerah untuk mendesainnya agar dapat efektif dan efisien. Partisipasi dari masyarakat dalam menumbuhkan kreatifitas dan meningkatkan produktivitas serta sekaligus meningkatkan tanggung jawabnya terhadap penggunaan dan hasil-hasilnya (Wardana, 2007).

Peningkatan mutu pendidikan menjadi sasaran pembangunan pendidikan nasional dan merupakan bagian integral dari upaya peningkatan kualitas manusia Indonesia secara menyeluruh (Mulyasa, 2005:31). Mutu pendidikan akan tercapai, apabila didukung oleh seluruh komponen dalam pendidikan yang terorganisir dengan baik. Komponen tersebut adalah input, procces, output, guru, sarana, prasarana, biaya, kesemuanya perlu mendapatkan dukungan sepenuhnya dari pihak yang mempunyai peran penting dalam lembaga pendidikan, dalam hal ini adalah kepala Sekolah. Kepala Sekolah merupakan pemimpin pendidikan yang berhubungan langsung dengan pelaksanaan program pendidikan di sekolah. Sebagai penentu kebijakan di sekolah, kepala sekolah harus memfungsikan perannya secara maksimal dan mampu memimpin Sekolah dengan bijak dan terarah, serta mengarah kepada pencapaian tujuan yang maksimal pula, demi meningkatkan mutu pendidikan (Munir, 2008). Pelaksanaan supervisi sebagai tugas dan tanggungjawab pengawas 
sekolah dari segi periode pelaksanaan, sasaran, dan fokus supervisi belum optimal dilakukan (Guntur, 2017).

Kepala sekolah mempunyai peran dan tanggung jawab terhadap keberhasilan proses belajar mengajar di kelas dalam sekup mikro atau di sekolah dalam sekup makro. Hal ini terkandung makna bahwa kepala sekolah sebagai manajer pendidikan adalah merencanakan sesuatu atau strategi yang baik, mengorganisasi dan mengkoordinasi sumber-sumber pendidikan yang berserakan agar menyatu dalam melaksanakan pendidikan, dan mengadakan kontrol terhadap pelaksanaan dan hasil pendidikan. Manajemen pendidikan ini merupakan usaha sistematis dan terkoordinasi secara terusmenerus memperbaiki kualitas layanan pendidikan, yang difokuskan kepada pelanggan pendidikan, dalam hal ini adalah peserta didik, orang tua peserta didik, pemakai lulusan, guru, karyawan, pemerintah dan masyarakat, sehingga dengan layanan pendidikan yang baik akan mengarah kepada pendidikan yang baik pula.

Madrasah memerlukan Kepala Madrasah yang memiliki kinerja yang mumpuni dan mampu mengelolan madrasah secara profesional dalam bidang kependidikan. Namun kenyataan di lapangan membuktikan bahwa tidak semua kepala Madrasah memenuhi kriteria yang ditentukan, tetapi lebih mengutamakan pada golongan ataupun kepangkatan yang dijalani melalui masa kerja. Peranan Kepala Madrasah sebagai administrator, manajer, dan supervisor pendidikan perlu dilengkapi dengan keterampilan manajerial. Sebagai manajer, Kepala Madrasah perlu mewujudkan sikap dan gaya kepemimpinan yang fleksibel, jujur, terbuka menerima kritik dan gagasan atau ide baru, demokratis, bertanggung jawab, terhadap tugas, berorientasi pada prestasi, kesetaraan (egaliter), mampu memberikan arahan dan bimbingan yang dibutuhkan warga Madrasah (Ramli, 2020).

Kepala madrasah merupakan salah satu unsur penting madrasah yang memiliki tugas dan fungsi yang sangat berpengaruh terhadap berlangsungnya proses madrasah. Karena itu, diperlukan Kepala Madrasah yang tangguh, yaitu Kepala Madrasah yang memiliki kompotensi yang mendukung tugas dan fungsinya dalam menjalankan proses madrasah (Wahed, 2016).

Menurut Peraturan Menteri Pendidikan Nasional Republik Indonesia Nomor 13 Tahun 2007, tentang Standar Kepala Sekolah/Madrasah Kepala Madrasah yang profesional selayaknya memenuhi 5 jenis standar kompetensi, yaitu: (1) Kompetensi Kepribadian, (2) Kompetensi Manajerial; (3) Kompetensi Kewirausahaan; (4) Kompetensi Supervisi, dan (5) Kompetensi Sosial.Kelima standar di atas sangat perlu dimiliki oleh Kepala Madrasah, karena akan berdampak pada peningkatan kualitas pendidik dan tenaga kependidikan, kuantitas dan kualitas sarana dan prasarana pendidikan, serta mutu dan prestasi peserta didik yang akan bermuara pada mutu madrasah yang dipimpinnya.

Penilaian diri sendiri (self-assessment) menjadi visi baru dalam evaluasi pembelajaran untuk kemajuan studi peserta didik. Model penilaian ini menghendaki peserta didik menilai pekerjaan mereka sendiri, berdasarkan bukti dan kriteria yang jelas, untuk tujuan memperbaiki kinerja masa depan (McMillan \& Hearn, 2008). Menurut Rolheiser \& Ross (2014) asesmen diri adalah suatu cara untuk melihat ke dalam diri sendiri. Melalui asesmen diri peserta didik dapat melihat kelebihan maupun kekurangannya, untuk selanjutnya kekurangan ini menjadi tujuan perbaikan (improvement goal). Dengan demikian, peserta didik lebih bertanggung jawab terhadap proses dan pencapaian tujuan belajarnya.

Self-assessment (penilaian diri sendiri) secara faktual akan melibatkan Kepala Madrasah dalam melakukan penilaian tentang kinerja mereka sendiri berdasarkan kegiatan atau pekerjaan yang telah mereka lakukan. Self-assessment (penilaian diri sendiri) memberikan kontribusi pada proses pencapaian Kepala Madrasah terutama untuk mengarahkan semua kemampuannya dalam mencapai target yang telah ditentukan. Di samping itu self assessment (penilaian diri sendiri) juga dapat dipergunakan untuk melakukan perbaikan terhadap kinerja Kepala Madrasah yang diketahui belum mencapai hasil seperti yang diharapkan.

Penggunaan istilah self assessment (penilaian diri sendiri) mencakup dua elemen kunci dalam setiap penilaian kinerja Kepala Madrasah yaitu pertama, penentuan kriteria atau standar 
yang diterapkan untuk menilai kinerja Kepala Madrasah dan kedua, melakukan penilaian terhadap sejauh mana hasil pekerjaan telah dicapai berdasarkan kriteria yang telah ditetapkan. Dalam kasus yang akan dibahas berikut ini, kriteria ditentukan oleh peneliti berdasarkan acuan yang sudah ada. Sedangkan Kepala Madrasah hanya terlibat dalam melakukan self assessment terhadap pekerjaan yang telah dilakukan.

Pada kenyataan dalam permasalahan di lapangan masih banyak terdapat kepala madrasah yang belum mengetahui tentang peningkatan diri sendiri. Di Kota Semarang sendiri khususnya pada MIN 6 Semarang ketidaktahuan kepala madrasah terhadap diri sendiri dapat dijelaskan saat peniliti mewawancarai dan menyebarkan angket terkait beberapa pertanyaan seputar peningkatan diri sendiri diperoleh untuk perkembangan kemampuan masih di bawah $60 \%$ untuk standar kepribadian, 56\% untuk kompentensi manajerial, 67\% untuk kompetensi kewiraushaan, 68\% untuk kompetensi supervisi dan 50\% untuk komptensi sosial. Oleh karena itu peneliti disini ingin mengetahui bagaimana perkembangan supervisi kepala madrasah untuk mengembangkan kinerja dalam mengelola sekolah Madrasah Ibtidaiyah Negeri dengan cara penelitian diri sendiri yang dilakukan secara berkala untuk perkembangan Kepala Madrasah Ibtidaiyah Negeri 6 Semarang.

\section{METODE PENELITIAN}

Penelitian ini merupakan penelitian tindakan kepengawasan, yaitu pencermatan terhadap kegiatan kepengawasan berupa sebuah tindakan, yang sengaja dimunculkan dan terjadi dalam satu madrasah binaan. Dalam pelaksanaannya peneliti dapat melakukan penelitian tindakan kepengawasan secara mandiri maupun kolaboratif partisifatif, akan tetapi tidak boleh menghambat kegiatan utama Kepala Madrasah dalam melaksanakan tugas dan tanggung jawabnya (Arikunto, 2008).

Penelitian ini dilakukan secara kolaboratif partisipatif, dimana Peneliti (Pengawas Sekolah pada Madrasah) secara bersama-sama dengan Subyek Penelitian (Kepala Madrasah) melaksanakan penelitian ini langkah demi langkah. Penelitian tindakan kepengawasan ini dilakukan oleh Peneliti bersama dengan Subyek Penelitian untuk mencoba menemukan suatu gagan- san yang kemudian diterapkan dalam upaya peningkatan kinerja Kepala Madrasah yang meliputi 5 standar, yaitu: (1) Standar Kepribadian; (2) Standar Kompetensi Manajerial; (3) Standar Kompetensi Kewirausahaan; (4) Standar Kompetensi Supervisi; dan (5) Standar Kompetensi Sosial. Metode yang diterapkan dalam penelitian tindakan kepengawasan ini adalah suatu metode penilaian yang menggunakan Self Assesment (Penilaian Diri Sendiri) dengan harapan dapat memberikan perubahan ke arah peningkatan kinerja Kepala Madrasah.

\section{HASIL DAN PEMBAHASAN}

\section{A. Hasil Penelitian dan Pembahasan Siklus 1 \\ 1. Perencanaan Tindakan pada Siklus 1}

Untuk mempermudah pelaksanaan tindakan maka perlu di- buat langkah-langkah suatu perencanaan. Langkah-langkah yang dilakukan dalam perencanaan tindakan pada Siklus 1, yaitu:

a. Peneliti mencetak blanko Instrumen Evaluasi Kinerja Kepala Madrasah;

b. Peneliti Menyampaikan blanko Instrumen Evaluasi Kinerja Kepala Madrasah kepada subyek penelitian untuk dipelajari, dipahami, dan ditanggapi;

c. Peneliti menerima tanggapan dari subyek penelitian tentang adanya komponenkomponen instrumen yang belum dipahami;

d. Peneliti memberikan penjelasan tentang komponen-komponen instrumen yang belum dipahami kepada subyek penelitian. Dan

e. Peneliti menyiapkan instrumen lain yang diperlukan untuk mengumpulkan data dan informasi selama dalam proses penelitian yang dilakukan. 


\section{Pelaksanaan Tindakan pada Siklus 1}

Langkah yang dilakukan pada waktu pelaksanaan tindakan pada Siklus 1 adalah:

a. Mengondisikan kesiapan subyek penelitian untuk mengisi blanko Instrumen Evaluasi Kinerja Kepala Madrasah secara obyektif;

b. Subyek Penelitian menyampaikan hasil isian Instrumen Evaluasi Kinerja Kepala Madrasah kepada Peneliti;

c. Peneliti menginput data isian Instrumen Evaluasi Kinerja Kepala Madrasah dan melakukan analisis dengan menggunakan aplikasi excell, sehingga diperoleh skor dan nilai persentase setiap butir instrumen;

d. Peneliti mencetak hasil analisis butir instrumen yang menampilkan skor, nilai, tabel dan grafik, tabel verifikasi, serta kesimpulan dan rekomendasi setiap komponen kompetensi; dan

e. Peneliti menyampaikan hasil analisis butir instrumen kepada Subyek Penelitian untuk dilakukan evaluasi dan menyiapkan tindakan selanjutnya.

\section{Pengamatan Tindakan pada Siklus 1}

Pada saat proses penilaian berlangsung, observer mengamati segala tindakan dan kebijakan yang dilakukan oleh Kepala Madrasah. Pengamatan tersebut meliputi segala aktivitas, kreativitas, dan inovasi yang dilakukan Kepala Madrasah untuk meningkatkan kualitas Pendidik dan Tenaga Kependidikan, kualitas dan prestasi peserta didik, serta kuantitas dan kualitas sarana dan prasarana pendidikan. Pada kegiatan pengamatan ini, peneliti menggunakan instrumen ob- servasi antara lain lembar observasi.

\section{Refleksi pada Siklus 1}

Peneliti dan Subyek Penelitian dalam tahapan ini secara bersama- sama melakukan refleksi untuk mengetahui dan memahami nilai setiap butir instrumen, selanjutnya melakukan analisis dan memaknai hasil tindakan Siklus 1. Apabila dalam hasil refleksi terdapat butir instrumen yang masih buruk, maka akan dilakukan pembenahan dan pemenuhan standar kompetensi pada Siklus 2. Pelaksanaan siklus 2 akan dilaksanakan setelah refleksi pada siklus 1. Apabila di dalam siklus 2 tersebut belum memenuhi kriteria yang ingin dicapai maka dilakukan siklus selanjutnya untuk memperbaiki kriteria yang sudah ditentukan.

\section{Analisis dan Pembahasan Hasil Evaluasi Kinerja Kepala Madrasah pada Siklus I}

Berdasarkan isian Instrumen Evaluasi Kinerja Kepala Madrasah Menggunakan Metode Self-Assesment (Penilaian Diri Sendiri) yang dilakukan oleh Subyek Penelitian pada Siklus 1 diperoleh informasi sebagai berikut:

\section{a. Standar Kepribadian pada Siklus 1}

Hasil analisis standar kepribadian menunjukkan bahwa butir Akhlak mulia memperoleh nilai $80 \%$, Kendali diri dalam memecahkan masalah memperoleh nilai $80 \%$, Sikap meyakinkan sebagai pemimpin memperoleh nilai 70\%, Penggerak pembaharuan memperoleh nilai $70 \%$, dan Sikap demokratis memperoleh nilai 100\%. Adapun butir Keteladanan memperoleh nilai 80\%, Sikap terbuka memperoleh nilai $80 \%$, Pemimpin pembelajar memperoleh nilai $80 \%$, Berbudaya mutu memperoleh nilai 80\%, dan Pembangun semangat bekerja keras memperoleh nilai $80 \%$. Dengan demikian persentase rata-rata capaian standar kepribadian memperoleh nilai $80 \%$ atau termasuk dalam kategori baik.

\section{b. Standar Kompetensi Manajerial pada Siklus 1}

Hasil analisis standar kompetensi manajerial menunjukkan bahwa butir Pengembangan visi dan misi memperoleh nilai $100 \%$, Dukungan pelaksanaan pembelajaran secara efektif memperoleh nilai $100 \%$, Pengembangan madrasah sebagai lingkungan belajar yang kondusif memperoleh nilai 80\%, Pengembagan kurikulum sesuai dengan kebutuhan pengembangan siswa memperoleh nilai $60 \%$, Penetapan sumber daya teknologi infomrasi dan komunikasi memperoleh nilai $70 \%$, dan Penetapan kerja sama internal yang akuntabel memperoleh nilai 
60\%. Adapun butir Penetapan target-target tertinggi yang realistik memperoleh nilai 100\%, Penerapan strategi pengelolaan yang bermutu memperoleh nilai 60\%, dan Penetapan kebijakan untuk meningkatkan kesejahteraan pendidik dan tenaga kependidikan memperoleh nilai $80 \%$, dan Penerapan standar dalam penerapan manajemen memperoleh nilai $80 \%$. Sedangkan butir Penetapan program bedasarkan analisis kebutuhan siswa memperoleh nilai $70 \%$. dan butir Data hasil evaluasi pengelolaan madrasah memperoleh nilai 60\%, Penetapan indikator keberhasilan memperoleh nilai $60 \%$, dan Penetapan perencanaan memperoleh nilai $80 \%$. Dengan demikian persentase rata-rata capaian standar kompetensi manajerial memperoleh nilai $76,4 \%$ atau termasuk dalam kategori buruk.

\section{c. Standar Kompetensi Kewirausahaan pada Siklus 1}

Hasil analisis Standar Kompetensi Kewirausahaan menunjukan bahwa butir Kemampuan Menganalisa Situasi memperoleh nilai 100\%, Pengembangan kewirausahaan sistem pengelolaan madrasah memperoleh nilai $100 \%$, Pelaksanaan kewirausahaan dalam sistem pengelolaan madrasah memperoleh nilai $60 \%$, Mengembangkan kewirausahaan warga madrasah memperoleh nilai $60 \%$, dan Mengembangkan kewirausahaan berbasis TIK memperoleh nilai 70\%. Adapun butir Mengembangkan kewirausahaan dalam diversifikasi sumber keuangan madrasah memperoleh nilai 60\%. Sedangkan butir Menghimpun data memperoleh nilai $100 \%$, dan Mengevaluasi pelaksanaan kewirausahaan madrasah memperoleh nilai $60 \%$. Dengan demikian persentase rata-rata capaian standar kompetensi Kewirausahaan memperoleh nilai 76,25\% atau termasuk dalam kategori baik.

\section{d. Standar Kompetensi Supervisi pada Siklus 1}

Hasil analisis Standar Kompetensi Supervisi menunjukkan bahwa butir Dokumen informasi kinerja supervisi, Mende- legasikan Pelaksanaan Supervisi memperoleh nilai 100\%, dan Mengolah data hasil Suvervisi memperoleh nilai 100\%. Adapun butir Merencanakan kegiatan supervisi memperoleh nilai 80\%, Melaksanakan Supervisi memperoleh nilai 80\%, Melibatkan pihak eksternal dalam meningkatkan penjaminan mutu memperoleh nilai $80 \%$, dan Menyelenggarakan supervisi terhadap kinerja penerapan 8 Standar Nasional Pendidikan memperoleh nilai $80 \%$. Sedangkan butir Menentukan target pelaksanaan memperoleh nilai $60 \%$, dan Kolaborasi dalam Pelaksanaan Supervisi memperoleh nilai 60\%, demikian pula dengan butir Menentukan bentuk apresiasi terhadap prestasi hanya memperoleh nilai $40 \%$. Dengan demikian persentase rata- rata capaian standar kompetensi Supervisi memperoleh nilai 78\% atau termasuk dalam kategori cukup.

\section{e. Standar Kompetensi Sosial pada Siklus 1}

Hasil analisis Standar Kompetensi Sosial menunjukkan bahwa butir Kerja sama internal memperoleh nilai 100\%, dan Berpartisipasi dalam kegiatan sosial memperoleh nilai $100 \%$. Adapun butir Pengembangan nilai sosial yang kolaboratif dan kompetitif memperoleh nilai $80 \%$. Sedangkan butir Kerjasama dalam Negeri memperoleh nilai 60\%, dan Bidang Kerjasama memperoleh nilai 60\%. Butir Kerjasama Luar Negeri memperoleh nilai 0\%. Dengan demikian persentase rata-rata capaian standar kompetensi Supervisi memperoleh nilai 63,3\% atau termasuk dalam kategori buruk. Berdasarkan hasil analisis data pada Siklus 1 diperoleh ratarata Kinerja Kepala Madrasah sebesar 74,8\% atau termasuk dalam kategori cukup.

\section{B. Hasil Penelitian dan Pembahasan Siklus 2 \\ 1. Perencanaan Tindakan pada Siklus 2}

Berdasarkan tindakan yang telah dilakukan pada Siklus 1, maka beberapa langkah pada Siklus 2 ini perlu diberikan penjelasan dan penekanan agar subyek penelitian memahami betul apa yang seharus- nya dilakukan. Langkah-langkah yang dilakukan dalam perencanaan tindakan pada Siklus 2, yaitu:

a. Peneliti mencetak blanko Instrumen Evaluasi Kinerja Kepala Madrasah;

b. Peneliti Menyampaikan blanko Instrumen Evaluasi Kinerja Kepala Madrasah kepada Subyek Penelitian sekaligus memberikan penjelasan yang cukup detail terhadap butirbutir kompetensi yang ada dalam instrumen tersebut; 
c. Peneliti dan subyek penelitian bersama-sama mendiskusikan langkah-langkah yang perlu diambil untuk mempercepat pemenuhan standar-standar yang telah ditetapkan;

d. Peneliti menyiapkan instrumen lain yang diperlukan untuk mengumpulkan data dan informasi selama dalam proses penelitian yang dilakukan.

\section{Pelaksanaan Tindakan pada Siklus 2}

Langkah yang dilakukan pada waktu pelaksanaan tindakan pada Siklus 2 adalah:

a. Mengondisikan kesiapan subyek penelitian untuk mengisi blanko Instrumen Evaluasi Kinerja Kepala Madrasah secara obyektif untuk kedua kalinya;

b. Subyek Penelitian menyampaikan hasil isian Instrumen Evaluasi Kinerja Kepala Madrasah kepada Peneliti;

c. Peneliti menginput data isian Instrumen Evaluasi Kinerja Kepala Madrasah dan melakukan analisis dengan menggunakan aplikasi excell, sehingga diperoleh skor dan nilai persentase setiap butir instrumen;

d. Peneliti mencetak hasil analisis butir instrumen yang menampilkan skor, nilai, tabel dan grafik, tabel verifikasi, serta kesimpulan dan rekomendasi setiap komponen kompetensi;

e. Peneliti menyampaikan hasil analisis butir instrumen kepada Subyek Penelitian untuk dilakukan evaluasi dan menyiapkan tindakan selanjutnya.

\section{Pengamatan Tindakan pada Siklus 2}

Pada saat proses penilaian berlangsung, observer mengamati segala tindakan dan kebijakan yang dilakukan oleh subyek penelitian. Pengamatan tersebut meliputi segala aktivitas, kreativitas, dan inovasi yang dilakukan Subyek Penelitian untuk meningkatkan kualitas Pendidik dan Tenaga Kependidikan, kualitas dan prestasi peserta didik, serta kuantitas dan kualitas sarana dan prasarana pendidikan. Pada kegiatan pengamatan ini, peneliti menggunakan instrumen ob- servasi antara lain lembar observasi.

\section{Refleksi pada Siklus 2}

Peneliti dan Subyek Penelitian dalam tahapan ini secara bersama- sama melakukan refleksi untuk mengetahui dan memahami nilai setiap butir instrumen selanjutnya melakukan analisis dan memaknai hasil tindakan siklus 2. Apabila di dalam siklus 2 tersebut belum memenuhi kriteria yang ingin dicapai maka dilakukan siklus selanjutnya untuk memperbaiki kriteria yang sudah ditentukan.

\section{Analisis dan Pembahasan Hasil Evaluasi Kinerja Kepala Madrasah pada Siklus 2}

Berdasarkan isian Instrumen Evaluasi Kinerja Kepala Madrasah Menggunakan Metode Self-Assesment (Penilaian Diri Sendiri) yang dilakukan oleh Subyek Penelitian pada Siklus 2 setelah melakukan perbaikan kinerjanya sebagai Kepala Madrasah, diperoleh informasi sebagai berikut:

\section{a. Standar Kepribadian pada Siklus 2}

Hasil analisis standar kepribadian menunjukkan bahwa butir Akhlak mulia memperoleh nilai $100 \%$, Sikap terbuka memperoleh nilai $100 \%$, Kendali diri dalam memecahkan masalah memperoleh nilai $100 \%$, Sikap meyakinkan sebagai pemimpin memperoleh nilai $90 \%$, Penggerak pembaharuan memperoleh nilai $80 \%$, Sikap demokratis memperoleh nilai $85,5 \%$, dan Berbudaya mutu memperoleh nilai $90 \%$. Adapun butir Keteladanan memperoleh nilai $90 \%$, Pemimpin pembelajar memperoleh nilai 90\%, dan Pembangun semangat bekerja keras memperoleh nilai $80 \%$. Dengan demikian persentase rata-rata capaian standar kepribadian memperoleh nilai $90,5 \%$ atau termasuk dalam kategori sangat baik.

\section{b. Standar Kompetensi Manajerial pada Siklus 2}

Hasil analisis standar kompetensi manajerial menunjukkan bahwa butir Pengembangan visi dan misi memperoleh nilai $100 \%$, Dukungan pelaksanaan pembelajaran secara efektif memperoleh nilai $100 \%$, Pengembangan madrasah sebagai lingkungan belajar yang kondusif 
memperoleh nilai $80 \%$, Pengembagan kurikulum sesuai dengan kebutuhan pengembangan siswa memperoleh nilai $100 \%$, Penetapan sumber daya teknologi infomrasi dan komunikasi memperoleh nilai 90\%, dan Penetapan kerja sama internal yang akuntabel memperoleh nilai $80 \%$. Adapun butir Penetapan program bedasarkan analisis kebutuhan siswa memperoleh nilai $100 \%$, Penetapan target-target tertinggi yang realistik memperoleh nilai 90\%, Penerapan strategi pengelolaan yang bermutu memperoleh nilai $80 \%$, dan Penetapan kebijakan untuk meningkatkan kesejateraan pendidik dan tenaga kependidikan memperoleh nilai $80 \%$, dan Penerapan standar dalam penerapan manajemen memperoleh nilai $80 \%$. Sedangkan butir Data hasil evaluasi pengelolaan madrasah memperoleh nilai 90\%, Penetapan indikator keberhasilan memperoleh nilai 90\%, dan Penetapan perencanaan memperoleh nilai 90\%. Dengan demikian persentase rata-rata capaian standar kompetensi manajerial memperoleh nilai $89,3 \%$ atau termasuk dalam kategori baik.

\section{c. Standar Kompetensi Kewirausahaan pada Siklus 2}

Hasil analisis Standar Kompetensi Kewirausahaan menunjukkan bahwa butir Kemampuan Menganalisa Situasi memperoleh nilai 100\%, Pengembangan kewirausahaan sistem pengelolaan madrasah memperoleh nilai $100 \%$, Pelaksanaan kewirausahaan dalam sistem pengelolaan madrasah memperoleh nilai $90 \%$, Mengembangkan kewirausahaan warga madrasah memperoleh nilai 90\%, dan Mengembangkan kewirausahaan berbasis TIK memperoleh nilai 90\%. Adapun butir Menghimpun data memperoleh nilai 80\%, Mengevaluasi pelaksanaan kewirausahaan madrasah memperoleh nilai $90 \%$, dan Mengembangkan kewirausahaan dalam diversifikasi sumber keuangan madrasah memperoleh nilai $100 \%$. Dengan demikian persentase rata-rata capaian standar kompetensi Kewirausahaan memperoleh nilai $91,25 \%$ atau termasuk dalam kategori sangat baik.

\section{d. Standar Kompetensi Supervisi pada Siklus 2}

Hasil analisis Standar Kompetensi Supervisi menunjukkan bahwa butir Dokumen informasi kinerja supervisi memperoleh nilai 100\%, Mendelegasikan Pelaksanaan Supervisi memperoleh nilai 100\%, dan Mengolah data hasil Suvervisi memperoleh nilai 100\%, Adapun butir Merencanakan kegiatan supervisi memperoleh nilai $80 \%$, Menentukan target pelaksanaan memperoleh nilai 80\%, Melaksanakan Supervisi memperoleh nilai 80\%, Kolaborasi dalam Pelaksanaan Supervisi memperoleh nilai $80 \%$, Melibatkan pihak eksternal dalam meningkatkan penjaminan mutu memperoleh nilai $80 \%$, Menentukan bentuk apresiasi terhadap prestasi memperoleh nilai $80 \%$, dan Menyelenggarakan supervisi terhadap kinerja penerapan 8 Standar Nasional Pendidikan memperoleh nilai $80 \%$. Dengan demikian persentase rata-rata capaian standar kompetensi Supervisi memperoleh nilai $86 \%$ atau termasuk dalam kategori baik.

\section{e. Standar Kompetensi Sosial pada Siklus 2}

Hasil analisis Standar Kompetensi Sosial menunjukkan bahwa butir Kerja sama internal memperoleh nilai 100\%, Bidang Kerjasama memperoleh nilai 100\%, Berpartisipasi dalam kegiatan sosial memperoleh nilai $100 \%$, dan Pengembangan nilai sosial yang kolaboratif dan kompetitif memperoleh nilai $80 \%$. Adapun butir Kerjasama dalam Negeri memperoleh nilai. Sedangkan butir Kerjasama Luar Negeri memperoleh nilai 0\%. Dengan demikian persentase rata-rata capaian standar kompetensi Sosial memperoleh nilai $76 \%$ aau termasuk dalam kategori cukup.

Berdasarkan hasil analisis data pada Siklus 2 diperoleh rata- rata Kinerja Kepala Madrasah sebesar 86,6\%, sehingga termasuk dalam kategori baik. Dengan demikian Perbandingan kinerja Kepala Madrasah berdasarkan analisis hasil Evaluasi Kinerja Kepala Madrasah dengan menggunakan Metode Self Assesment (Penilaian Diri Sendiri) pada Siklus 1 dan 2, di mana pada Siklus 1 diperoleh rata-rata sebesar 74,8\% (cukup) dan Siklus 2 diperoleh rata-rata sebesar $86,6 \%$ (baik), maka terjadi peningkatan sebesar 11,8\%, sehingga dapat disimpulkan bahwa Penggunaan Metode Self Assesment (Penilaian Diri Sendiri) dapat meningkatkan Kinerja Kepala Madrasah.

Hasil penelitian ini sejalan dengan hasil penelitian yang dilakukan oleh Ramli (2020) yang menyatakan bahwa penggunaan Metode Self Assesment (Penilaian Diri Sendiri) dapat 
menjadikan tolak ukur untuk menjadikan peningkatan supervisi kepala MAN Di Kota Sorong. Dari penelitian tersebut di atas membuktikan bahwa metode Metode Self Assesment (Penilaian Diri Sendiri) sangat cocok diterapkan pada kepala Madrasah Ibtidaiyah Negeri.

\section{KESIMPULAN}

Berdasarkan hasil analisis data dan pembahasan yang telah peneliti lakukan terhadap kinerja Kepala Madrasah, dapat ditarik kesimpulan sebagai berikut:

1. Kinerja Kepala Madrasah dapat ditingkatkan dengan menggunakan metode Self Assesment (Penilaian Diri Sendiri);

2. Peningkatan Kinerja Kepala Madrasah dengan menggunakan metode Self Assesment (Penilaian Diri Sendiri) dari 74,8\% pada Siklus 1 menjadi 86,6\% pada Siklus 2 atau terjadi peningkatan sebesar $11,8 \%$;

\section{DAFTAR PUSTAKA}

Arikunto, Suharsimi. (2008). Penelitian Tindakan Kelas. Jakarta: Bumi Aksara

Arikunto, Suharsimi. (2012). Dasar-Dasar Evaluasi Pendidikan. Jakarta: PT. Bumi Aksara

Guntur, Abdul Yunus., Tri Joko Raharjo, dan Wahyu Lestari. (2017). Pengembangan Model Supervisi Akademik Berbasis Evaluasi Diri bagi Guru SMA. Educational Management, EM. 5 (1).

McMillan, J. H. and Hearn, J. (2008). Student Slef-Assessment: The Key to Stronger Student Motivation and Higher Achievement. Virginia: educational HORIZON.

Mulyasa, E. (2005). Menjadi Guru professional. Bandung: PT. Remaja Rosdakarya,

Munir, Abdullah. (2008). Menjadi Kepala Sekolah Efektif. Yogyakarta: ArRuzz Media.

Peraturan Menteri Pendidikan Nasional Nomor 13 Tahun 2007 tentang Standar Kepala Sekolah/Madrasah

Ramli, Muhammad. (2020). Meningkatkan Kinerja Kepala MAN Model Kota Sorong Melalui Metode Self Assesment (Penilaian Diri Sendiri). Al-Riwayah: Jurnal Kependidikan, $12(1)$

Riduwan. (2009). Skala Pengukuran Variabel-Variabel Penelitian. Bandung: Alfabeta

Rolheiser, C. \& Ross, J. A. (2005). Student Self-Evaluation: What Research Says and What Practice Shows.

Slameto. (2010). Belajar dan Faktor-Faktor yang Mempengaruhi. Jakarta: Rineka Cipta

Sudjana, Nana. (2006). Penilaian Hasil Proses Belajar Mengajar. Bandung: PT. Remaja Rosdakarya

Suryabrata, Sumadi. (2006). Psikologi Pendidikan. Jakarta: PT. Raja Grafindo Per- sada

Susilo. (2007). Panduan Penelitian Tindakan Kelas. Yogyakarta: Pustaka Book Publlisher

Wahed, Abdul. (2016). Model Kepemimpinan Kepala Madrasah Dan Permasalahannya. AlIbrah, Vol. 1 No.1

Wardana Yana. (2007). Manajemen Pendidikan Untuk Peningkatan Daya Saing Bangsa. Bandung: Pribumi Mekar.

Wiriaatmadja, Rochiati. (2009). Metode Penelitian Tindakan Kelas. Bandung: PT. Remaja Rosdakarya 